\title{
Possibility of culturing Pacific goliath grouper Epinephelus quinquefasciatus in water with different salinities
}

\author{
Posibilidad de cultivo del mero guasa del Pacífico Epinephelus \\ quinquefasciatus en aguas de diferentes salinidades
}

\author{
Lury García N, ${ }^{1 *}$ M.Sc, Frank Chapman Ch, ${ }^{2}$ Ph.D.
}

\begin{abstract}
${ }^{1}$ Universidad del Pacífico, Programa de Tecnología en Acuicultura, Av Simón Bolívar \# 54A-10 Los Laureles, Buenaventura-Valle del Cauca, Colombia. ${ }^{2}$ University of Florida, Program Fisheries and Aquatic Sciences, 7922 NW 71st Street, Gainesville-Florida 32653, USA. ${ }^{*}$ Correspondencia: lurynohemyg3@gmail.com; fchapman@ufl.edu
\end{abstract}

Received: March 2014; Accepted: November 2014.

\begin{abstract}
Objective. To assess the survival and growth of juvenile Pacific goliath grouper (Epinephelus quinquefasciatus) in captivity at low salinities. Materials and methods. We randomly selected twelve juvenile goliath groupers with an average standard length of $44.2 \pm 6.1 \mathrm{~cm}$ and $1492 \pm 476 \mathrm{~g}$ in body weight, and raised them for three months in the laboratory in waters of 32-26, 20, 10 and 5 parts per thousand of salinity. Results. All juvenile Pacific goliath groupers tolerated the initial gradual transfer from full strength seawater to salinities of 32-26,20,10, and 5 parts per thousand, which was done over a period of four days. All of them survived and grew in body weight and length during the course of the three-month experiment, in all the treatments of high and low salinity water. The body condition factor $(\mathrm{K})$ for each fish was between 1.5 and 2.4. Conclusions. This is a first time trial that documents a randomized, controlled experiment demonstrating the ability of Pacific juvenile goliath grouper to gradually transfer from full strength seawater to water of lower salinity, and survive and grow well in these brackish waters.
\end{abstract}

Key words: Aquaculture, euryhaline species, osmoregulation, water salinity (Source: BNA, NAL).

\section{RESUMEN}

Objetivo. Evaluar la supervivencia y crecimiento de mero guasa del Pacifico (Epinephelus quinquefasciatus) a bajas salinidades en cautiverio. Materiales y métodos. Se seleccionaron al azar doce juveniles de mero guasa de una longitud estándar promedio de $44.2 \pm 6.1 \mathrm{~cm}$ y $1492 \pm 476 \mathrm{~g}$ de peso corporal, que fueron criados por tres meses en el laboratorio en aguas de 32-26, 20, 10, y 5 unidades prácticas de salinidad (UPS). Resultados. Todos los juveniles de mero guasa toleraron la transferencia gradual, que se realizó en cuatro días, desde agua de mar a aguas con salinidades de 32-26, 20, 10, y 5 UPS. Igualmente todos sobrevivieron los tres meses, y presentaron ganancia en peso y longitud corporal en todos los tratamientos con niveles altos y bajos de salinidad. Los factores de condición corporal $(K)$, para cada pez estuvieron entre 1.5 y 2.4. Conclusiones. Por primera vez se documenta un experimento de prueba aleatoria controlada; que demuestra la habilidad de juveniles de mero guasa del Pacífico, a poder adaptarse de agua marina a salinidades más bajas que las de su medio ambiente natural, y de crecer en ellas con total supervivencia.

Palabras clave: Acuicultura, especies eurihalinas, osmoregulación, salinidad del agua (Fuente: BNA, NAL). 


\section{INTRODUCTION}

The resources that draw greater commercial interest in the marine fish industry in Colombia are shrimps, lobster, tunas, snappers, mackerels and groupers (1). Of the grouper the most desired is the goliath grouper, its flesh is considered excellent, and high prices in the local and international market are obtained. It is a large species that reaches up to $455 \mathrm{~kg}$ in weight and $2.5 \mathrm{~m}$ long (2). The biological and ecological characteristics of the species indicate great adaptability to captivity and the ability to endure environmental fluctuations, including salinity (3-5). In captivity, individual fish from $0.5-3.5 \mathrm{~kg}$ more than double their weight in 90 to 240 days (3). It could be a marine fish species adaptable to diversification of aquaculture in Colombia. However, there is little information about its adaptability to low salinity conditions and culturing the species under these circumstances (3-5).

Marine aquaculture, including grouper, is principally done in cages suspended in protected areas of the sea or in channels and tanks in farms by the sea (6). Although culturing in cages in the sea is the simplest and most economic initial solution, a viable alternative that protects the environment, economic growth, social and cultural sustainability, principally in Colombia, is culturing marine fish inland (opinion of the authors of this study). Also in the opinion of the authors is that the principal advantages of culturing marine fish in the inland is the possibility of improved control over the environment where the animals are bred, predator control, the option to apply a feeding ration protocol that is efficient and results in weight gain and growth, feeding at required times, and reducing food waste that often occurs in cages, thus lowering feeding costs and increasing the productive efficiency of fish culture.

From the point of view of environmental sustainability, culturing marine fish inland could make use of saline water and land that is not apt for agriculture or farming. Breeding marine fish with a high commercial value would enable a diversification of production risks and profitability, and would offer new opportunities for economic growth and employment in the rural sector. This is especially true for the costal populations that are characterized by having a culture and life style immersed in a mix of traditional agriculture and artisan fishing.

In a recent study it was shown that grouper has the anatomic and physiologic mechanisms

\section{INTRODUCCIÓN}

Los recursos de mayor interés comercial de la pesca marítima industrial en Colombia son los camarones, langosta, atunes, pargos, sierras, chernas y meros (1). De los meros, el guasa es de los más apetecidos, su carne es considerada excelente, y obtiene altos precios tanto en el mercado local como internacional. Es una especie de gran tamaño, alcanza hasta $455 \mathrm{~kg}$ de peso y $2.5 \mathrm{~m}$ de longitud (2). Las características biológicas y ecológicas de la especie indican gran adaptabilidad de su medio ambiente al cautiverio y a soportar amplias fluctuaciones ambientales, incluyendo la salinidad (3-5). En cautiverio individuos de $0.5-3.5 \mathrm{~kg}$ alcanzaron más del doble de su peso en 90 a 240 días (3). Puede ser una especie de pez marino adecuada para la diversificación de la acuicultura en Colombia. Sin embargo, existe poca información sobre su adaptabilidad a condiciones de baja salinidad y del cultivo de la especie en estas circunstancias (3-5).

La acuicultura marina, incluyendo la del mero, se práctica principalmente en jaulas suspendidas en áreas protegidas en el mar o en canales y estanques en granjas junto al mar (6). Aunque el cultivo en jaulas en el mar es la solución inicial más sencilla y económica, una alternativa viable para la protección del medio ambiente, crecimiento económico, y sostenibilidad social como cultural, principalmente en Colombia, es el cultivo de peces marinos en tierra adentro (opinión de los autores de este estudio). Es opinión también de los autores, de las principales ventajas del cultivo de peces marinos tierra adentro es la posibilidad de controlar mejor el ambiente en donde se crían los animales, el control de predadores, opción de aplicar un protocolo de ración alimentaria que muestre eficiencia y ganancia de peso y crecimiento de los animales, alimentar cuando sea requerido, y reducir el desperdicio de comida que ocurre con mayor frecuencia en jaulas, disminuyendo de esta forma los costos de alimentación y aumentando la eficiencia productiva del cultivo.

Desde el punto de vista de sostenibilidad ambiental, el cultivo de peces marinos en tierra adentro podría hacer uso de aguas y tierras salinas no aptas para agricultura o ganadería. El cultivo de peces marinos de alto valor comercial haría diversificar riesgos de producción y rentabilidad, y ofrecería nuevas oportunidades de crecimiento económico y empleo en el sector rural. Lo anterior, especialmente en las poblaciones costeras que se caracterizan por tener una cultura y estilo de vida inmersas en una mezcla de agricultura tradicional y pesca artesanal.

En un reciente estudio se demostró que el mero guasa tiene los mecanismos anatómicos y fisiológicos de osmoregulación que les permite mantener un adecuado balance de sales y agua en ambientes 
of osmoregulation that allows them to keep an adequate balance of salts and water in environments both fresh water and salt water (5). In static bioassays of acute toxicity of 96 hours (CL50-96h) in water with low salinity, the survival of the bass depends on weight (greater than $160 \mathrm{~g}$ ) or body size (5).

Populations of goliath grouper are found on both coasts of Colombia and the species is recognized as Epinephelus itajara in the majority of texts. Recently the population of the Pacific was designed with the scientific name $E$. quinquefasciatus or Pacific goliath grouper (7). Although genetically different, up to now no apparent differences in the biological and ecological characteristics between the two populations have been observed. In the same way, individuals of both populations have demonstrated a great adaptability in captivity (5). Similarities in the results and interpretation between the two species can thus be assumed.

The objective of this study was to evaluate the survival and growth of Pacific goliath grouper (Epinephelus quinquefasciatus) in brackish water.

\section{MATERIALS AND METHODS}

Study site. Experiments were done at the Fish Culture Station facilities of the National Aquiculture and Fishing Authority (AUNAP) Bahía Málaga on the Pacific coast, Valle del Cauca, Colombia $\left(04^{\circ} 06^{\prime} 00^{\prime \prime} \mathrm{N}\right.$; 77²1'00" O).

Animals in the experiment. The groupers were young Epinephelus quinquefasciatus (species previously known as E. itajara) collected from the natural marine environment (26-32 parts per thousand of salinity or pps; $35 \mathrm{pps}=35 \mathrm{~g}$ of salt per liter of solution) close to the station, transported in plastic containers without sedatives, acclimated to captivity in floating cages $(3 \times 3 \times 2 \mathrm{~m}$ with plastic mesh openings of $2.5 \mathrm{~cm}$ ) in the ocean (26-32 pps and $28-32^{\circ} \mathrm{C}$ ), and kept at a density of $20 \mathrm{~kg} /$ $\mathrm{m}^{3}$ in inanition for a week before beginning the experiment to ease transition to feeding in captivity.

Identification, handling of specimens and obtaining different salinities. From the group, 12 fish were selected with a standard average length (SL) of $44.2 \pm 6.1 \mathrm{~cm}$ and $1492 \pm 476$ of weight; even when the number of fish was low, and there was high standard deviation, each individual represented an independent variable or standard since in this tanto de agua dulce y agua salada (5). En bioensayos estáticos de toxicidad aguda de 96 horas (CL50-96h) en aguas de baja salinidades, la supervivencia de los meros depende de su peso (mayor de $160 \mathrm{~g}$ ) 0 volumen corporal (5).

Poblaciones de mero guasa se encuentran en ambas costas de Colombia y la especie es reconocida como Epinephelus itajara, en la mayoría de los textos. Recientemente a la población del Pacífico se le designó el nombre científico de $E$. quinquefasciatus o mero guasa del Pacífico (7). Aunque genéticamente diferentes, hasta el momento no se han observado diferencias aparentes en las características biológicas y ecológicas entre las dos poblaciones. Igualmente individuos de ambas poblaciones han demostradó gran adaptabilidad al cautiverio (5). Se puede asumir entonces similitudes en los resultados e interpretación entre las dos especies.

El objetivo de este trabajo fue evaluar la supervivencia y crecimiento de mero guasa (Epinephelus quinquefasciatus) a bajas salinidades en cautiverio

\section{MATERIALES Y MÉTODOS}

Sitio de estudio. Los experimentos se realizaron en la instalaciones de la Estación Piscícola de la Autoridad Nacional de Acuicultura y Pesca (AUNAP) Bahía Málaga en la costa Pacífica, Valle del Cauca, Colombia (0406'00" N; 77²1'00" O).

Animales experimentales. Los meros fueron juveniles de Epinephelus quinquefasciatus (especie antes conocida como E. itajara) recolectados del medio natural marino (26-32 unidades prácticas de salinidad o ups; 35 ups $=35$ g de sal por litro de solución) en cercanías a la estación, transportados en vasijas de plástico sin sedante, aclimatados al cautiverio en jaulas flotantes ( $3 \times 3 \times 2 \mathrm{~m}$ con ojo de malla plástica de $2.5 \mathrm{~cm}$ ) en el mar (26-32 ups y $28-32^{\circ} \mathrm{C}$ ), y mantenidos a una densidad de $20 \mathrm{~kg} / \mathrm{m}^{3}$ en inanición por una semana antes de comenzar el experimento para facilitar la transición al alimento en cautiverio.

Identificación, manejo de especímenes y obtención de las diferentes salinidades. Del grupo, se seleccionaron al azar 12 ejemplares de una longitud estándar (LE) promedio de $44.2 \pm 6.1 \mathrm{~cm}$ y $1492 \pm 476 \mathrm{~g}$ de peso; aun cuando el número de ejemplares fue bajo, y desviación estándar alta, cada individuo representa una variable o muestra independiente ya que en este tipo de aclimatación (supervivencia y crecimiento) expresa la singularidad fisiológica de cada individuo y no necesariamente de grupo alguno; la comparacion de estas variables entre grupos es solo de referencia y descripción. Estos 
type of acclimation (survival or growth), the physiological singularity of each individual and not necessarily of any group is expressed; the comparison of these variables between groups is only a reference and description. These were taken to the laboratory and were randomly equally divided into 4 tanks with salinities of $5,10,20$ and $26-32$ ppt; the required salinities were obtained by diluting marine water in fresh water until reaching the required salinity which was verified with a refractometer; the salinity of salt water fluctuated between 26 and $32 \mathrm{ppt}$.

Acclimation to the desired salinity was gradually done over $4 \mathrm{~d}$. The salinity was reduced sea water at 20 ppt during one hour, and kept at this salinity for $24 \mathrm{~h}$; then it was reduced by $15 \mathrm{ppt}$ during one hour and kept at that salinity for 24 $\mathrm{h}$; then it was reduced by $8 \mathrm{ppt}$ and kept at that salinity for $48 \mathrm{~h}$, and finally during one hour the complete transition to fresh water was made. Each fish was marked with a small cut on its fin.

Captivity location and feeding of the specimens. The experiment was performed in tanks of $1500 \mathrm{I}(2 \times 1 \times 1 \mathrm{~m})$, with an interchange of $20 \%$ to $30 \%$ daily, and constant oxygenation; each system was randomly measured for oxygen, temperature, and salinity with a multiparameter instrument (YSI 85, YSI, Inc., U.S.A.). The fish were fed two times a day with pieces of fresh fish (Opistonema libertate) at $4 \%$ its total weight. This percentage was used so as not to introduce too much organic material in the system and thus be able to control the quality of the water.

\section{Survival, feeding, recording measurements} and duration of the study. During the experiment it was observed that the survival of individuals and their individual feeding behavior as: consumption or rejection of feed. The assay was done over 12 weeks and every two weeks the fish were individually sampled, with the total weight recorded $(\mathrm{g})$, total length and standard $(\mathrm{cm})$. With this data the averages of weight and size were obtained, both initial and final, the percentage of weight gained, and the condition factor $\left(K=\right.$ weight $* 100 /$ Length $\left.^{3.056}\right)$ of each individual; the condition factor was used to evaluate the state of health of the individuals during the experiment. At the end of the experiment the survival rate was calculated.

Data analysis. Data was organized and analyzed using descriptive and parametric statistics with a level of reliability at 95\% (alpha of 0.05), on Excel sheets (Excel ver. 12.0, Microsoft Corporation, U.S.A.), Barlett test to establish homogeneity of the variables, and the t-test from Student. se llevaron al laboratorio y dividieron igualmente al azar en 4 tanques con salinidades de 5,10 , 20 y 26-32 ups; las salinidades requeridas se obtuvieron diluyendo el agua marina con agua dulce, hasta alcanzar la salinidad requerida la cual fue verificada con un refractómetro; la salinidad del agua marina fluctuó entre 26 y 32 ups.

La aclimatación a la salinidad deseada se hizo gradualmente durante $4 \mathrm{~d}$. La salinidad fue reducida de agua de mar a 20 ups en una hora, y mantenidos a esa salinidad por $24 \mathrm{~h}$; luego reducida a 15 ups en una hora y mantenidos a esa salinidad por $24 \mathrm{~h}$; luego reducida a 8 ups y mantenidos a esa salinidad por $48 \mathrm{~h}$, y finalmente se hizo en una hora la transición completa hasta agua dulce. Cada pez fue marcado con un pequeño corte en la aleta.

Sitio de cautiverio y alimentación de especímenes. El experimento se realizó en tanques de $1500 \mathrm{I}(2 \times 1 \times 1 \mathrm{~m})$, con intercambio de $20 \%$ al $30 \%$ diario, y aireación constante; cada semana se midió aleatoriamente el oxígeno, temperatura, y salinidad con un instrumento multiparámetro (YSI 85, YSI, Inc., U.S.A.). Los peces se alimentaron dos veces al día con trozos de pescado fresco (Opistonema libertate) a razón de $4 \%$ de su peso total. Se utilizó este porcentaje con el fin de no introducir demasiada materia orgánica al sistema y así controlar la calidad de agua.

Supervivencia, alimentación, registro de medidas y duración del estudio. Durante el experimento se observó la supervivencia de individuos y comportamiento alimentario individual como: consumo o rechazo del alimento. El ensayo se mantuvo por 12 semanas y cada 15 días los peces fueron muestreados individualmente, registrándose peso total $(\mathrm{g})$, longitud total y estándar $(\mathrm{cm})$. Con estos datos se obtuvieron los promedios de peso y talla, tanto inicial como final, el porcentaje de peso ganado, y el factor de condición ( $K=$ peso*100/Longitud ${ }^{3.056}$ ) de cada individuo; el factor de condición fue utilizado para evaluar el estado de salud de los individuos durante el experimento. Al final del experimento se calculó el porcentaje de supervivencia.

Análisis de los datos. Los datos fueron organizados y analizados utilizando estadística descriptiva y paramétrica con un nivel de confiabilidad del 95\% (alpha de 0.05), en hojas de cálculo Excel (Excel ver. 12.0, Microsoft Corporation, U.S.A.), test de Barlett para establecer homogeneidad de las varianzas, y el t-test de Student. 


\section{RESULTS}

All the young grouper survived the initial acclimation by gradual transfer that was done in four days, from sea water to water with salinities of 32 a 26, 20, 10 and 5 ppt. All the specimens survived the three months of treatment with high and low levels of salinity (Table 1). The fish also easily accepted the consistent feeding of pieces of fresh fish. In every treatment each fish increased in weight and size; but growth rates were very variable so no significant differences were detected $(p>0.05)$ between different salinities (Table 1 ). Body condition factors for each fish were between 1.5 and 2.4 (Table 1 ).

\section{RESULTADOS}

Todos los juveniles de mero resistieron la aclimatación inicial de transferencia gradual que se realizó en cuatro días, del agua de mar a agua con salinidades de 32 a 26, 20, 10 y 5 ups. Todos los especímenes sobrevivieron los 3 meses de tratamiento a niveles altos y bajos de salinidad (Tabla 1). Los peces también aceptaron fácilmente el alimento consistente de trozos de pescado fresco. En cada uno de los tratamientos cada pez incrementó en peso y talla; pero las tasas de crecimiento fueron muy variables así que no se detectaron diferencias significativas $(p>0.05)$ entre las diferentes salinidades (Tabla 1). Los factores de condición corporal para cada pez estuvieron entre 1.5 y 2.4 (Tabla 1 ).

Table 1. Values of total length, body weight, growth and condition factor for Pacific goliath grouper (Epinephelus quinquefasciatus) in different salinities (parts per thousand of salinity ppt) during a three month period at temperatures between $24.1^{\circ} \mathrm{C}$ and $28.0^{\circ} \mathrm{C}$. The predicted values were estimated using the model of relation length-weight reported in FishBase, a digital fish encyclopedia, for E. itajara (2).

\begin{tabular}{|c|c|c|c|c|c|}
\hline Salinty and Fish & $\begin{array}{c}\text { Length }(\mathrm{cm}) ; \\
\text { Initial Weight }(\mathrm{g})\end{array}$ & $\begin{array}{c}\text { Length }(\mathrm{cm}) ; \\
\text { Final weight }(\mathrm{g})\end{array}$ & Weight gained (\%) & $\begin{array}{c}\text { Condition factor } \\
\text { (K) }\end{array}$ & Survival (individuals) \\
\hline 5 ppt average & $41.5 ; 1310$ & $43.3 ; 1467$ & 12.0 & $1.5-2.3$ & $100 \%$ \\
\hline 1 & $36.0 ; 800$ & $37.0 ; 1150$ & 43.8 & 2.3 & (1) \\
\hline 2 & $41.5 ; 1300$ & $43.0 ; 1400$ & 7.7 & 1.8 & (1) \\
\hline 3 & $47.0 ; 1750$ & $50.0 ; 1850$ & 5.7 & 1.5 & (1) \\
\hline $10 \mathrm{ppt}$ average & $38.5 ; 1050$ & $40.6 ; 1283$ & 32.0 & $1.6-2.4$ & $100 \%$ \\
\hline 4 & $30.0 ; 500$ & $32.0 ; 800$ & 60.0 & 2.4 & (1) \\
\hline 5 & $40.0 ; 1000$ & $42.0 ; 1300$ & 30.0 & 1.8 & (1) \\
\hline 6 & $45.5 ; 1650$ & $48.0 ; 1750$ & 6.1 & 1.6 & (1) \\
\hline 20 ppt average & $47.8 ; 1800$ & $50.6 ; 1967$ & 9.2 & $1.5-1.6$ & $100 \%$ \\
\hline 7 & $47.5 ; 1750$ & $50.0 ; 1950$ & 11.4 & 1.6 & (1) \\
\hline 8 & $48.0 ; 1750$ & $50.0 ; 1850$ & 5.7 & 1.5 & (1) \\
\hline 9 & $48.0 ; 1900$ & $52.0 ; 2100$ & 10.5 & 1.5 & (1) \\
\hline 26-32 ppt average & $49.0 ; 1833$ & $50.8 ; 2083$ & 13.4 & $1.5-1.7$ & $100 \%$ \\
\hline 10 & $47.5 ; 1750$ & $49.5 ; 1850$ & 5.7 & 1.5 & (1) \\
\hline 11 & $50.5 ; 1850$ & $51.5 ; 2050$ & 10.8 & 1.5 & (1) \\
\hline $\begin{array}{c}12 \\
(28-32 \mathrm{ppt}) \text { Nature }\end{array}$ & $\begin{array}{c}49.0 ; 1900 \\
\text { Predicted }\end{array}$ & $\begin{array}{l}51.5 ; 2350 \\
\text { Predicted } \\
45.1489\end{array}$ & $\begin{array}{l}23.7 \\
\text { Predicted }\end{array}$ & $\begin{array}{l}1.7 \\
\text { Predicted }\end{array}$ & (1) \\
\hline
\end{tabular}

\section{DISCUSSION}

In this study, the possible similarity in the osmorregulatory adaption of the Pacific goliath grouper population with that of its congener described in the Atlantic (5) is discussed. For the first time an experiment is documented that shows the ability of young Pacific goliath grouper to be gradually transferred from sea water to lower salinities than those of its natural environment and grow in them with complete survival over a period of three months. The corporal condition factors for each fish were between 1.5 and 2.4 (Table 1); similar estimates to the range factors of theoretical condition of 1.6, determined for grouper bass of a similar size captured and predicted by the length-weight relation model reported in

\section{DISCUSIÓN}

En este estudio, se destaca posible similitud en adaptación osmorregulatoria de la población de mero guasa del Pacífico con la de su congénere descrita en el Atlántico (5). Por primera vez se documenta un experimento que demuestra la habilidad de juveniles de mero guasa del Pacífico de ser gradualmente transferidos de agua marina a salinidades más bajas que las de su ambiente natural y de crecer en ellas con total supervivencia durante un período de tres meses. Los factores de condición corporal para cada pez estuvieron entre 1.5 y 2.4 (Tabla 1), estimativos similares a los rangos del factor de condición teórico de 1.6, determinados para los meros guasa de similar talla capturados en la naturaleza y predichos por el modelo de la relación longitud-peso reportados en la enciclopedia computarizada de peces FishBase (2). El 
the digital fish encyclopedia FishBase (2). The fact that all the fish survived in good health and bodily conformation (k), similar or larger when compared to grouper found in nature, is a significant result of this study and shows the possibility of breeding the species in water with different salinities.

The survival and growth in good health in salinity of 5 ppt is also a good result, since Woo \& Wu (8) and $\mathrm{Wu} \&$ Woo (9) reported that the osmoregulatory capacity in other species of grouper was only between 7 and 30 ppt and these were the only results reported in recent literature. Although the optimal salinity for breeding was not determined, in the experimental salinity of $10 \mathrm{ppt}$ (isosmotic) similar results were observed and even better growth to that observed in a natural environment with salinities around 28-32 ppt, with the explanation that the osmoregulatory processes require energy, so that salt water environments that diminish energy needs help to maximize the growth of the species.

In the case of gilt-headed bream, Sparus aurata, marine species considered to be eurohaline, it has been clearly demonstrated that greater growth occurs when they are acclimated at $12 \mathrm{ppt}$ and not at 6 or $38 \mathrm{ppt}$ (10). Even so, the exact mechanism of the effect of salinity in growth is not completely understood (11). Additionally, during this experiment the grouper were docile and easily adapted to captivity, although some of them had leeches. In other grouper species a lower incidence of diseases especially in waters with lower salinity was noted $(8,9)$.

For several years, a variety of grouper have been commercially cultivated, principally in China, Japan, Taiwan, Southeast Asia and the Middle East, but these practices are mainly based on collecting young fish in the wild and fattening them in captivity until they are at commercial size (6). Sustainable aquaculture practices, however, should depend on seed obtained under domestic conditions. The purpose of this study was to initiate investigations about the growth possibility of grouper in low salinity or freshwater conditions. Eventually the purpose is to organize a group of producers to develop the production technology of eggs and young fish. This is for the aquaculture of marine species in coastal areas or inland in Colombia, an attractive proposition, especially for reducing risks inherent in breeding in cages at high sea, in relation to activities like maintaining, repairing production structures, caring for fish, disease hecho de que todos los ejemplares hayan sobrevivido con buen estado de salud y conformación del cuerpo $(\mathrm{K})$, similar o mayor en comparación con el de meros encontrados en el medio natural, es un resultado significativo de este estudio y refleja la posibilidad del cultivo de la especie en aguas de diferentes salinidades.

El sobrevivir y crecer en buen estado de salud en salinidad de 5 ups, también son resultados alentadores ya que Woo \& Wu (8) y Wu \& Woo (9) reportaron que la capacidad osmorreguladora en otras especies de meros fue sólo entre 7 y 30 ups; siendo estos los únicos resultados reportados en la literatura reciente. Aunque no se determinó la salinidad óptima de cultivo, en la salinidad experimental de 10 ups (isosmótica) se observó similar y hasta mejor crecimiento al observado en el medio natural con salinidades alrededor de 2832 ups; teniendo como explicación que los procesos osmorreguladores requieren de energía, así que salinidades ambientales que disminuyan estas necesidades energéticas ayudarían a maximizar el crecimiento de la especie.

En el caso de la dorada Sparus aurata, especie marina considerada eurohalina, ha quedado claramente demostrado un mayor crecimiento cuando estan aclimatadas a 12 ups y no a 6 ni 38 ups (10). Aun asi, el mecanismo exacto del efecto de la salinidad en el crecimiento no está completamente esclarecido (11). Adicionalmente durante éste experimento los meros demostraron docilidad y facilidad de adaptación al cautiverio, aunque se detectaron en algunos de ellos infestaciones con sanguijuelas. En otras especies de meros se ha comprobado menor incidencia de enfermedades especialmete en aguas de baja salinidad $(8,9)$.

Por varios años, se han cultivado a nivel comercial, varias especies de mero principalmente en China, Japón, Taiwán, el sudeste de Asia y oriente medio, pero estas prácticas se basan principalmente en la recolección de juveniles en el medio silvestre y su engorde en cautiverio hasta tamaño comercial (6). Prácticas de acuicultura sostenible, sin embargo, deben depender de la semilla obtenida bajo condiciones domésticas. El propósito de este estudio fue iniciar investigaciones sobre la posibilidad de crecimiento de mero guasa en condiciones salobres o de agua dulce. Eventualmente con el propósito de conformar un plantel de reproductores para el desarrollo de la tecnología de producción de huevos y juveniles de la especie. Esto por cuanto la acuicultura de especies marinas en las zonas costeras o en tierra adentro de Colombia es una propuesta atractiva, especialmente en la reducción de los riesgos inherentes al cultivo en jaulas en alta mar, en relación con actividades como el mantenimiento y reparación de estructuras de producción, cuidado de los peces, la transmisión de enfermedades a las poblaciones naturales y la 
in natural populations and contaminating the benthic community. Additionally, property conflicts, public perfection, and technical matters in selecting the site make it more and more difficult to do ocean aquiculture. The great osmoregulatory capacity of the young of this species (5), as well as the proven capacity to adapt to captivity $(3,4)$, are indicators of the potential of culturing this species in Colombia, not just in marine environments, but also in low salinity and even freshwater conditions.

\section{Acknowledgement}

To the fishermen, students at the Universidad del Pacífico, and the leaders at the AUNAP in Bahía Málaga for making the staff available and allowing the use of their installations. contaminación de la comunidad bentónica. Además, los conflictos de propiedad, la percepción pública, y cuestiones técnicas en la selección del sitio, hace cada véz más difícil la acuicultura oceánica. La amplia capacidad osmorreguladora de los juveniles de la especie (5), así como su comprobada capacidad de adaptación al cautiverio $(3,4)$ son indicadores del potencial del cultivo de la especie en Colombia, no sólo en ambientes marinos, sino en condiciones salobres y hasta en agua dulce.

\section{Agradecimientos}

A los pescadores, estudiantes de la Universidad del Pacífico, y directivos de la AUNAP en Bahía Málaga por la disposición del personal y permitir la utilización de las instalaciones.

\section{REFERENCIAS}

1. FAO. Resumen informativo sobre la pesca: República de Colombia. Roma: FAO FID/CP/ COL Rev. 6; 2003.

2. FishBase. Atlantic goliath grouper. Lengthweight parameters for Epinephelus itajara; (fecha de acceso 1 enero 2014). URL disponible en: http://www.fishbase.org.

3. Cervigón, F. La acuicultura en Venezuela: estado actual y perspectivas. Caracas: Editorial Artes; 1983.

4. Botero J, Ospina JF. Crecimiento y desempeño general de juveniles silvestres de mero guasa Epinephelus itajara (Lichtenstein) mantenidos en jaulas flotantes bajo diferentes condiciones de cultivo. Bol Investig Mar Costeras 2003; 32:25-36.

5. García LN, Sierra CL, Perez J, Esquivel F, Chapman FA. Osmoregulation of juvenile marine goliath grouper (Epinephelus itajara) in low-salinity water. Rev Colom Cienc Pecu 2013; 26:127-135.

6. Pierre S, Gaillard S, Prévot-D'alvise N, Aubert J, Rostaing-Capaillon O, LeungTack D, Grillasca JP. Grouper aquaculture: Asian success and Mediterranean trials. Aquatic Conserv: Mar Freshw Ecosyst 2008; 18:297-308.
7. Craig MT, Graham RT, Torres RA, Hyde JR, Freitas MO, Ferreira BP, Hostim-Silva $M$, Gerhardinger LC, Bertoncini AA, Robertson DR. How many species of goliath grouper are there? Cryptic genetic divergence in a threatened marine fish and the resurrection of a geopolitical species. Endang Species Res 2009; 7:167-174.

8. Woo NYS, Wu RSS. Metabolic and osmoregulatory changes in response to reduced salinities in the red grouper Epinephelus akaara (Temminck \& Schlegel), and the black sea bream, Mylio macrocephalus (Basilewsky). J Exp Mar Biol Ecol 1982; 65:139-161.

9. Wu RSS, Woo NYS. Tolerance of hypoosmotic salinities in thirteen species of adult marine fish: implications for estuarine fish culture. Aquacult 1983; 32:175-181.

10. Laiz-Carrión R, Sangiao-Alvarellos S, Guzmán JM, Martín del Río MP, Soengas JL, Mancera JM. Growth performance of gilthead sea bream Sparus aurata in different osmotic conditions: implications for osmoregulation and energy metabolism. Aquacult 2005; 250:849-861.

11. Boeuf G, Payan P. How should salinity influence fish growth? Comp Biochem Phys C 2001; 130:411-423. 